\title{
ANALISIS KEMAMPUAN LITERASI SAINS FISIKA SISWA SMA PADA MATERI KINEMATIKA GERAK LURUS DI MASA PANDEMI COVID-19
}

\author{
Farikhatul Mukharomah', Wiyanto' dan Ngurah Made Darma Putra1 \\ ${ }_{1}^{1}$ Pendidikan Fisika, Pascasarjana, Universitas Negeri Semarang, Jl. Kelud Utara III, Semarang, \\ 50237, Indonesia \\ E-mail: farikha.karimah66@students.unnes.ac.id
}

\begin{abstract}
ABSTRAK
Pembelajaran daring di masa pandemi Covid-19 yang tidak maksimal memberikan dampak terhadap kemampuan literasi sains, termasuk literasi sains fisika. Terlebih fakta di Indoensia, kemampuan literasi sains siswa masih rendah menurut hasil PISA. Oleh karena itu, diperlukan upaya untuk meningkatkan kemampuan literasi sains siswa. Tujuan penelitian ini adalah untuk menganalisis kemampuan awal literasi sains fisika siswa kelas X MIPA SMA Negeri 1 Jepara di masa pandemi Covid-19. Penelitian ini termasuk penelitian deskriptif kuantitatif. Sampel penelitian ini adalah 71 siswa kelas X MIPA SMA Negeri 1 Jepara. Data dikumpulkan dengan wawancara dan tes secara online. Domain kemampuan literasi sains yang diukur adalah domain kompetensi. Hasil penelitian menunjukkan bahwa kemampuan literasi sains fisika siswa pada materi kinematika gerak lurus pada domain kompetensi sebesar 57,50\% masih dalam kategori pencapaian "rendah". Oleh sebab itu, kemampuan literasi sains fisika siswa perlu ditingkatkan. Salah satu faktor rendahnya kemampuan literasi sains fisika ini adalah proses pembelajaran daring yang belum menerapkan kegiatan praktikum. Maka dari itu, upaya untuk meningkatkan kemampuan literasi sains fisika tersebut dapat dilakukan dengan cara melakukan kegiatan praktikum berbasis literasi sains secara daring.
\end{abstract}

Kata kunci: Pandemi Covid-19, Kemampuan Literasi Sains, Fisika, Kinematika Gerak Lurus

\begin{abstract}
Online learning during the Covid-19 pandemic that was not optimal had an impact on scientific literacy skills, including physical science literacy. Moreover, the fact in Indonesia, students' scientific literacy is still low according to the PISA results. Therefore, efforts are needed to improve students' scientific literacy. The purpose of this study was to determine and analyze the physics scientific literacy of students of class X MIPA SMA Negeri 1 Jepara. This type of research is a quantitative descriptive study. The sample of this study was 71 students of class X MIPA SMA Negeri 1 Jepara. Data were collected by interviews and online test. The domain of scientific literacy that is measured is the competency domain. The results showed that the students' physics scientific literacy in the kinematics of linear motion in the competency domain of $57.50 \%$ was still in the "low" achievement category. Therefore, students' physics scientific literacy needs to be improved. One of factors for the low of the physics scientific literacy is the online learning process that has not implemented practicum activities. One of the efforts to improve the scientific literacy of physics is by carrying out practicum activities by online based on scientific literacy.
\end{abstract}

Keywords: Covid-19 pandemic, Scientific Literacy, Physics, Linear Motion Kinematics

DOI: $\underline{\text { http://dx.doi.org/10.15575/jotalp.v6i1.10391 }}$

Received: 3 Desember 2020 ; Accepted: 6 Februari 2021 ; Published: 28 Febriari 2021 


\section{PENDAHULUAN}

Indonesia tengah dihadapkan dengan mewabahnya virus Corona yang kini dikenal dengan masa pandemi Covid-19. Hal ini berakibat pada sektor pendidikan, sehingga Kementrian Pendidikan dan Kebudayaan menetapkan pembelajaran tatap muka dialihkan menjadi pembelajaran daring. Tentunya, pembelajaran daring ini tidak mudah diterima oleh pembelajaran pada topik sains (Naila \& Khasna, 2021). Hal ini tentu akan berdampak pada kemampuan literasi sains siswa. Dimana, literasi sains merupakan aspek penting yang dapat dijadikan bekal bagi generasi zaman sekarang dalam upaya untuk menghadapi perkembangan teknologi yang semakin canggih (Andini F, et. al., 2020).

Keterampilan literasi sains harus dimiliki oleh peserta didik, karena literasi sains juga merupakan keterampilan yang diperlukan pada abad 21 (Pertiwi et al., 2018). Menurut WEFUSA (2015), literasi sains merupakan salah satu keterampilan yang diperlukan di abad 21 diantara 16 keterampilan yang diidentifikasi oleh World Economic Forum. Keterampilan abad 21 berguna untuk mengatasi tantangan perkembangan ilmu pengetahuan dan teknologi (IPTEK) dan untuk memastikan daya saing peserta didik di era globalisasi (Turiman et al., 2012). Hal ini sejalan dengan pendapat Nofiana (2017) bahwa salah satu kunci sukses menghadapi tantangan abad 21 di era globalisasi adalah "melek sains" (science literacy), karena salah satu sumber daya manusia (SDM) yang dapat bersaing dan dapat menyiapkan peserta didik yang terampil di bidangnya dan memiliki keterampilan berpikir kreatif adalah individu yang melek sains.

Literasi sains didefinisikan sebagai kemampuan setiap individu untuk mengaplikasikan pengetahan dalam memecahkan masalah yang berkaitan dengan sains dan teknologi dalam kehidupan sehari-hari, mengikutsertakan pertimbangan wacana tentang sains dan teknologi yang membutuhkan kompetensi untuk menjelaskan fenomena secara ilmiah, mengevaluasi dan mendesain penyelidikan ilmiah, serta menginterpretasi data dan buktibukti secara ilmiah (OECD, 2015a). American Association for the Advancement of Science (AAAS) (1990) menyusun framework dan mendeskripsikan karakter seseorang dikatakan sebagai orang yang berliterasi yaitu orang yang mampu mengaitkan antara sains, matematika, dan teknologi. Sehingga, dapat disimpulkan bahwa literasi sains merupakan kemampuan seseorang dalam memecahkan masalah dalam kehidupan sehari-hari dengan cara mengaitkan antara sains, matematika, dan teknologi.

Kemampuan literasi sains siswa Indonesia masih tergolong rendah dan mengalami penurunan, menurut hasil penilaian Programme for International Student Assesment (PISA). Pada bidang literasi sains, hasil penilaian PISA tahun 2015 menunjukkan bahwa siswa Indonesia hanya mencapai skor 403 dari rata-rata skor negaranegara OECD yakni 493 (OECD, 2015b). Sementara hasil penilaian PISA tahun 2018, siswa Indonesia mengalami penurunan skor menjadi 396 dari rata-rata skor negara-negara OECD yakni 489 (OECD, 2018). Kemampuan literasi sains siswa dipengaruhi oleh beberapa faktor yaitu 1) bahan ajar, 2) model pembelajaran, 3) media pembelajaran, 4) lembar kerja siswa, 5) alat evaluasi yang berbasis literasi sains (A. Rusilowati et al., 2019). Rendahnya kemampuan literasi sains siswa dimungkinkan karena kelima faktor tersebut belum diterapkan dalam proses pembelajaran.

Menurut PISA, pengukuran kemampuan literasi sains didasari oleh 4 domain, yaitu: 1) Domain konteks, yakni penilaian terhadap pengetahuan dan kompetensi peserta didik dalam konteks tertentu (pribadi, lokal/nasional, dan global); 2) Domain kompetensi, meliputi kemampuan menjelaskan fenomena secara ilmiah, mengevaluasi dan merancang penyelidikan ilmiah, serta menginterpretasi data dan bukti secara ilmiah; 3) Domain pengetahuan, meliputi pengetahuan konten, prosedural, dan epistemik; 
4) Domain sikap, menunjukkan minat pada sains, dukungan untuk penyelidikan ilmiah, dan motivasi untuk bertindak secara bertanggungjawab terhadap, misalnya, sumber daya alam dan lingkungan (OECD, 2015a).

Kemampuan literasi sains yang diukur oleh PISA mencakup pula bidang ilmu Fisika. Fisika adalah cabang ilmu sains yang dapat dikaji literasi sainsnya (Nurwulandari, 2018). Salah satu kunci keberhasilan peningkatan kemampuan peserta didik dalam menyesuaikan diri dengan perubahan zaman dan memasuki dunia teknologi adalah pengembangan kemampuannya dalam bidang ilmu Fisika (Indrawati, 2018). Oleh karena itu, pengukuran literasi sains siswa dalam bidang ilmu fisika sangat diperlukan. Salah satu materi fisika yang termasuk dalam konten literasi sains adalah materi kinematika gerak lurus. Hasil penelitian Adani et al., (2018) menyimpulkan bahwa literasi sains siswa pada materi gerak lurus dikategorikan rendah.

Berdasarkan penjelasan tersebut, penelitian ini bertujuan untuk menganalisis kemampuan literasi sains fisika siswa pada materi kinematika gerak lurus di masa pandemi Covid-19. Hasil penelitian ini akan dijadikan sebagai acuan bagaimana upaya-upaya peningkatan kemampuan literasi sains fisika siswa pada materi kinematika gerak lurus di masa pandemi Covid-19.

\section{METODE PENELITIAN}

Penelitian ini termasuk penelitian deskriptif kuantitatif. Penelitian ini menggambarkan suatu keadaan nyata dengan tidak memberikan perlakuan, pengubahan variabel bebas atau manipulasi (Sukmadinata, 2012). Data yang dikumpulkan, kemudian diolah dan disajikan apa adanya.

Penelitian ini dilaksanakan bulan Oktober 2020 di masa pandemi Covid-19. Populasi penelitian ini adalah siswa kelas X MIPA SMA Negeri 1 Jepara. Teknik pengambilan sampel penelitian ini adalah cluster random sampling. Sampel penelitian ini adalah 71 siswa dari dua kelas yakni X MIPA 3 dan X MIPA 4.

Teknik pengumpulan data dilakukan menggunakan wawancara dan tes. Wawancara dilakukan dengan guru fisika mengenai proses pembelajaran daring mata pelajaran fisika. Tes dilakukan melalui Forms Microsoft Office 365. Instrumen tes yang digunakan adalah 6 butir soal essai. Soal tersebut merupakan soal fisika berbasis literasi sains materi kinematika gerak lurus yang diadopsi dari penelitian Yulianti (2020). Pengukuran kemampuan literasi sains dapat dilakukan dengan cara menganalisis penguasaan siswa dalam setiap domain literasi sains (Ani Rusilowati et al., 2016). Pada penelitian ini, domain kemampuan literasi sains yang diukur adalah domain kompetensi. Indikator dari domain kompetensi di antaranya adalah menjelaskan fenomena secara ilmiah, mengevaluasi dan mendesain penyelidikan ilmiah, dan menginterpretasi data dan bukti secara ilmiah (OECD, 2015a).

Analisis data dilakukan menggunakan persentase ketercapaian kemampuan literasi sains fisika pada domain kompetensi. Adapun interpretasi data dari persentase ketercapaian kemampuan literasi sains fisika pada domain kompetensi ditunjukkan oleh Tabel 1.

Tabel 1. Kategori Interpretasi Data Skor (Purwanto, 2013)

\begin{tabular}{cc}
\hline Kategori & Interval \\
\hline Sangat Tinggi & $86-100$ \\
\hline Tinggi & $76-85$ \\
\hline Sedang & $60-75$ \\
\hline Rendah & $55-59$ \\
\hline Sangat Rendah & $<54$ \\
\hline
\end{tabular}

\section{HASIL DAN PEMBAHASAN}

Hasil pengolahan data ketercapaian kemampuan literasi sains fisika siswa kelas X MIPA 3 dan X MIPA 4 SMA Negeri 1 Jepara pada materi 
kinematika gerak lurus ditunjukkan pada Tabel 2. Berdasarkan Tabel 2 terlihat bahwa kemampuan literasi sains fisika siswa pada domain kompetensi secara keseluruhan adalah 57,50\% berada pada kategori ketercapaian "rendah". Di antara ketiga indikator domain kompetensi yang memiliki hasil yang lebih tinggi adalah indikator mengevaluasi dan mendesain penyelidikan ilmiah yaitu $62,30 \%$ berada pada kategori ketercapaian "sedang". Selanjutnya hasil indikator menjelaskan fenomena secara ilmiah adalah 58,05\% berada pada kategori ketercapaian "rendah". Sedangkan indikator domain kompetensi yang memiliki ketercapaian paling rendah adalah menginterpretasi data dan bukti ilmiah yaitu $52,15 \%$ berada pada kategori ketercapaian "rendah".

\section{Menjelaskan Fenomena Secara Ilmiah}

Indikator domain kompetensi "Menjelaskan Fenomena Secara Ilmiah" memiliki indikator khusus yaitu mengingat dan menerapkan pengetahuan ilmiah yang sesuai, mengidentifikasi, menggunakan, dan menghasilkan representasi yang jelas, membuat dan membenarkan prediksi yang tepat, menawarkan hipotesis penjelasan, menjelaskan implikasi potensial dari pengetahuan ilmiah untuk masyarakat (OECD, 2015a). Indikator ini terdapat pada soal nomor 1 dan 4 .

Pada soal nomor 1, siswa diharapkan mampu menawarkan hipotesis penjelasan dari sebuah peristiwa gerak lurus beraturan dan gerak lurus berubah beraturan. Pernyataan soalnya sebagai berikut:

Mobil A dan mobil B sedang bergerak lurus di sepanjang jalan tol yang memiliki batas maksimum kecepatan. Suatu saat kedua mobil bergerak berdampingan (kecepatan sama). Tak lama kemudian, mobil A bergerak mendahului mobil B. Setelah mendahului mobil $B$, mobil $A$ dianggap melampaui batas maksimum kecepatan. Ternyata di depan mereka ada polisi yang bertugas. Sehingga mobil A terkena razia. Jika mobil $B$ selalu bergerak dengan kecepatan konstan, apakah mobil B juga melampaui batas kecepatan dan terkena razia? Berikan hipotesismu.

Mayoritas siswa hanya menggambarkan dan secara parsial memberikan penjelasan sederhana. Sampel jawaban siswa disajikan pada Gambar 1 berikut.

3 Mobil B tidak alkan terkena razia karema mobil B menjakanlan deman kecepaton Verstan

Gambar 1. Sampel Jawaban Siswa Nomor 1 Yang Sederhana

Hanya 6 dari 71 siswa yang mendapatkan skor 7 . Siswa tersebut mampu memberikan beberapa penjelasan beserta fakta yang mendukung dari peristiwa GLB dan GLBB. Sampel jawaban siswa yang lebih detail ditunjukkan pada Gambar 2.

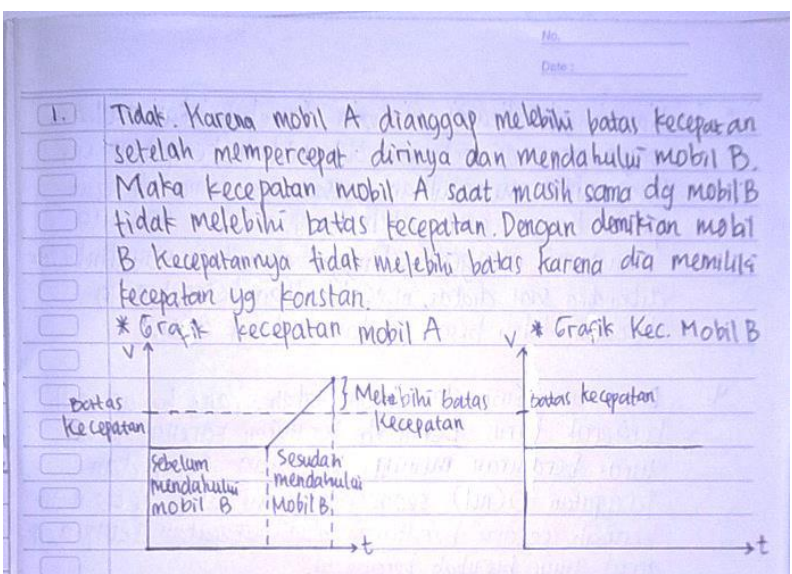

Gambar 2. Sampel Jawaban Siswa No. 1 Yang Lebih Detail

Pada soal nomor 4, siswa juga diharapkan mampu menawarkan hipotesis penjelasan dari sebuah penyajian data hasil percobaan, seperti yang ditunjukkan Gambar 3. Pada soal tersebut telah disajikan 3 grafik yang menggambarkan suatu jenis gerak lurus, yakni gerak lurus berubah beraturan (GLBB) dipercepat. 
Tabel 2. Kemampuan Literasi Sains Fisika Siswa Kelas X MIPA SMA Negeri 1 Jepara

\begin{tabular}{ccccc}
\hline No. & Indikator Domain Kompetensi & Nomor Soal & Hasil (\%) & Kategori \\
\hline 1 & Menjelaskan fenomena secara ilmiah & 1,4 & 58,05 & Rendah \\
\hline 2 & Mengevaluasi dan mendesain penyelidikan ilmiah & 3,5 & 62,30 & Sedang \\
\hline 3 & Menginterpretasi data dan bukti ilmiah & 2,6 & 52,15 & Rendah \\
\hline \multicolumn{7}{r}{ Kemampuan Literasi Sains Fisika Domain Kompetensi } & 57,50 & Rendah \\
\hline
\end{tabular}
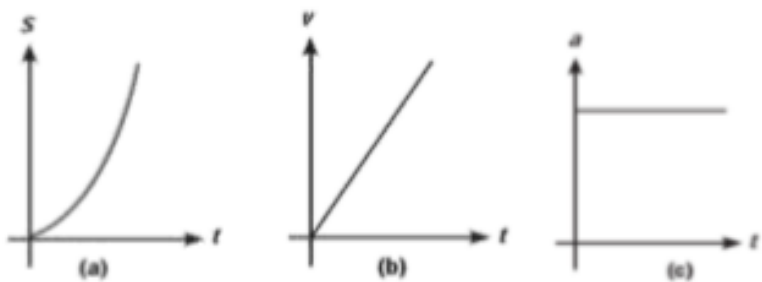

Gambar 3. Grafik Soal Nomor 3

Akan tetapi, banyak siswa menjawab seperti pada Gambar 4. Hal ini memberikan informasi bahwa siswa belum dapat mengidentifikasi, menggunakan, dan menghasilkan representasi yang jelas. Siswa belum dapat membedakan grafik s terhadap $\mathrm{t}, \mathrm{v}$ terhadap $\mathrm{t}$, dan a terhadap $\mathrm{t}$.

$\operatorname{Gambar}(a)=$ lintasan GLBB
Gambar $(b)=$ Jarak tempuh GLB
$\operatorname{Gambar}(c)=$ Tridak bergerak.

Gambar 4. Sampel Jawaban Siswa Nomor 4 Yang Tidak Tepat

Di antara 71 siswa yang dapat menawarkan hipotesis penjelasan dari ketiga grafik tersebut dengan tepat adalah hanya 3 siswa. Berikut adalah contoh jawaban tepat siswa.

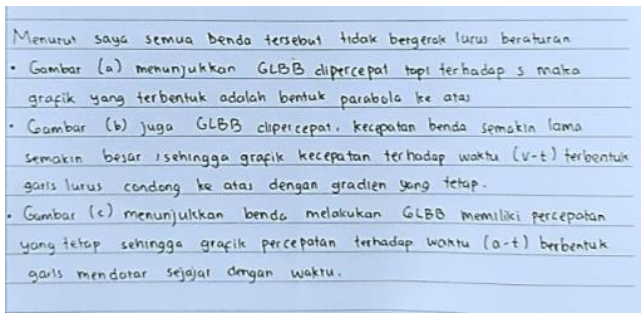

Gambar 5. Sampel Jawaban Siswa Nomor 4 Yang Tepat

\section{Mengevaluasi Dan \\ Mendesain Penyelidikan Ilmiah}

Indikator domain kompetensi "Mengevaluasi Dan Mendesain Penyelidikan Ilmiah" memiliki indikator khusus yaitu mengidentifikasi pertanyaan yang diselidiki dalam studi ilmiah tertentu, membedakan pertanyaan yang mungkin untuk diselidiki secara ilmiah, mengusulkan cara menyelidiki pertanyaan yang diberikan secara ilmiah, mengevaluasi cara menyelidiki pertanyaan yang diberikan secara ilmiah, serta menjelaskan dan mengevaluasi berbagai cara yang digunakan para ilmuwan untuk memastikan kebenaran data dan objektivitas serta penjelasan secara umum (OECD, 2015a). Indikator ini terdapat pada soal nomor 3 dan 5 .

Pada soal nomor 3, siswa diharapkan mampu mengevaluasi cara menyelidiki pertanyaan yang diberikan secara ilmiah mengenai kombinasi gerak vertikal atas dan gerak jatuh bebas seperti Gambar 6 berikut.

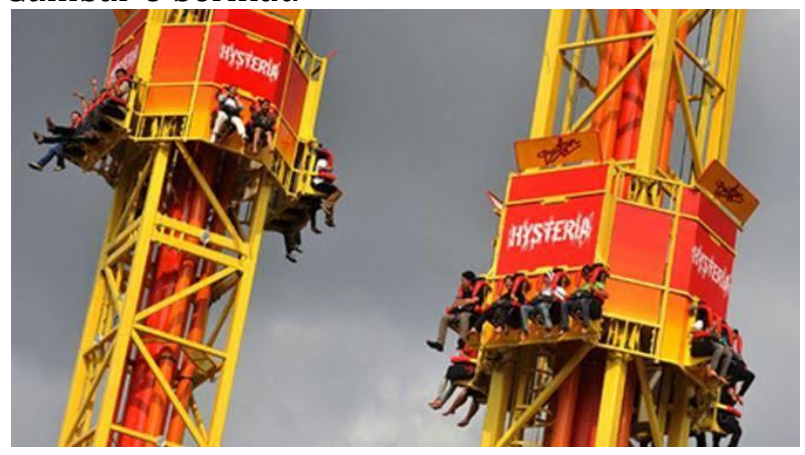

Gambar 6. Wahana Hysteria

Mayoritas siswa hanya dapat menggambarkan dan secara parsial memberikan penjelasan sederhana. Bahwa untuk mencapai titik tertinggi wahana hysteria memerlukan kecepatan lebih besar dari pada kecepatan untuk turun ke bawah 
karena adanya pengaruh gravitasi. Sampel jawaban siswa disajikan pada Gambar 7 berikut.

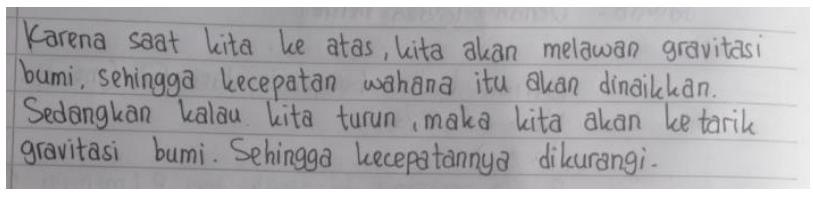

Gambar 7. Sampel Jawaban Siswa Nomor 3 Yang Sederhana

Terdapat 15 siswa dari 71 siswa yang mampu menjawab dengan tepat. Siswa tersebut mampu memberikan beberapa penjelasan beserta fakta yang mendukung dari peristiwa kombinasi gerak vertikal atas dan gerak jatuh bebas. Sampel jawaban siswa disajikan pada Gambar 8 berikut.

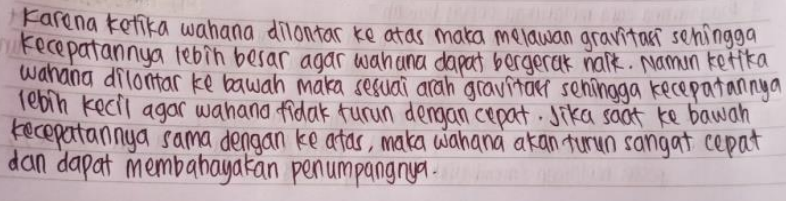

Gambar 8. Sampel Jawaban Siswa Nomor 3 Beserta Fakta Pendukung

Pada soal nomor 5, siswa diharapkan membedakan pertanyaan yang mungkin untuk diselidiki secara ilmiah mengenai peristiwa gerak jatuh bebas. Ketika pensil dan selembar kertas dijatuhkan secara bersamaan, maka yang jatuh terlebih dahulu adalah pensil. Jawaban tersebut memang benar, akan tetapi alasan siswa kurang tepat. Sampel jawaban siswa disajikan pada Gambar 9 berikut.

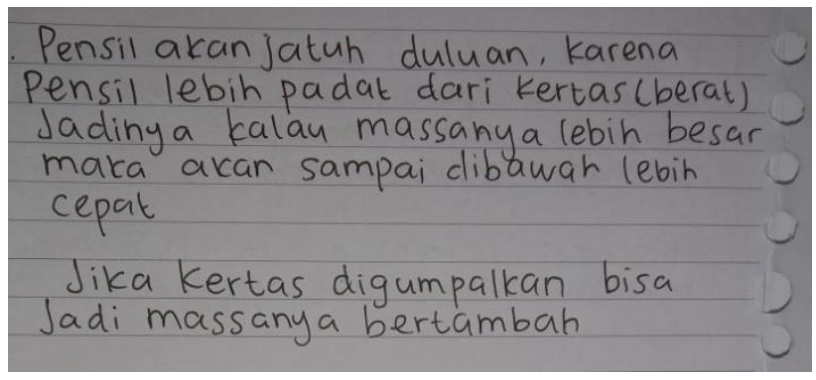

Gambar 9. Sampel Jawaban Siswa Nomor 5 Yang Kurang Tepat
Siswa menganggap bahwa peristiwa tersebut terjadi karena massa pensil lebih besar dari selembar kertas. Padahal, peristiwa gerak jatuh bebas tidak dipengaruhi oleh massa (Firdaus T et.al., 2019).

Peristiwa jatuhnya pensil terlebih dahulu daripada selembar kertas adalah karena dipengaruhi oleh hambatan udara. Adapun ketika siswa diberi pertanyaan pembanding, jika selembar kertas tersebut digumpalkan, siswa tetap menganggap bahwa pensil yang akan jatuh terlebih dahulu. Sedangkan jawaban yang tepat adalah pensil dan gumpalan kertas tersebut akan jatuh secara bersamaan. Hal ini karena tidak ada yang dipengaruhi oleh hambatan udara. Adapun besaran fisika yang memengaruhi gerak jatuh bebas adalah percepatan gravitasi saja ketika benda dijatuhkan dari ketinggian yang sama. Pada soal nomor 5 ini yang dapat menjawab dengan tepat hanya 2 siswa. Siswa yang lain ada yang menjawab benar tapi belum disertai fakta pendukung.

\section{Menginterpretasi Data Dan Bukti Ilmiah}

Indikator domain kompetensi "Menginterpretasi Data Dan Bukti Ilmiah" memiliki indikator khusus yaitu mengubah data dari satu representasi ke representasi lainnya, menganalisis serta menginterpretasikan data dan menarik kesimpulan yang tepat, mengidentifikasi asumsi, bukti dan penalaran dalam teks yang berhubungan dengan sains, membedakan argumen yang didasarkan pada bukti ilmiah dan teori yang didasarkan pada pertimbangan, dan mengevaluasi argumen dan bukti ilmiah dari berbagai sumber (misalnya surat kabar, internet, jurnal) (OECD, 2015a). Indikator ini terdapat pada nomor soal 2 dan 6 .

Pada soal nomor 2, siswa diharapkan mampu mengidentifikasi asumsi, bukti, dan penalaran dalam teks yang berhubungan dengan sains. Bumi berotasi dengan nilai kelajuan konstan yang besar, dan kita tidak merasakan gerakan tersebut. Sebuah kereta api yang sedang melaju biasanya 
dicontohkan sebagai gerak lurus beraturan. Ini dapat diartikan bahwa kecepatan kereta api tersebut konstan. Akan tetapi, kita dapat merasakan bahwa kereta api tersebut sedang bergerak. Beberapa siswa menjawab bahwa hal itu dikarenakan ukuran Bumi yang lebih besar dari kereta api. Jawaban tersebut tidaklah menandakan bahwa siswa mampu mengidentifikasi asumsi, bukti dan menalar dengan baik. Sampel jawaban siswa disajikan pada Gambar 10.

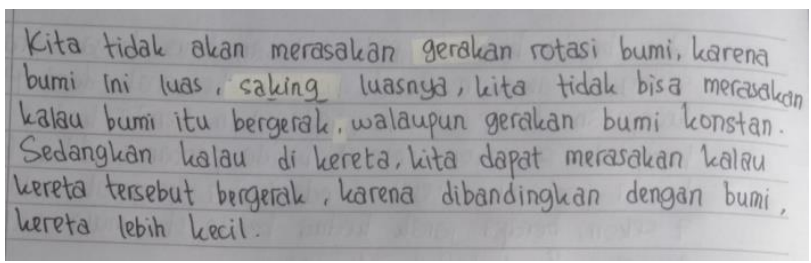

Gambar 10. Sampel Jawaban Siswa Nomor 2 Yang Tidak Tepat

Pada soal nomor 6, siswa diharapkan mampu menganalisis, menginterpretasi data dan menarik kesimpulan yang tepat mengenai gerak jatuh bebas. Suatu peristiwa pertandingan terjun payung, peserta membuka parasutnya di ketinggian yang berbeda. Dengan mengaitkan peristiwa tersebut dengan konsep gerak jatuh bebas, siswa dapat menarik kesimpulan peserta mana yang cepat mendarat.

Beberapa siswa menjawab bahwa peserta yang membuka parasut lebih awal (ketinggiannya lebih tinggi dari peserta lain), maka peserta tersebut akan lebih cepat mendarat karena ada persiapan. Dari jawaban tersebut, siswa tersebut belum mampu menginterpretasi data ketinggian untuk dianalisis ke konsep gerak jatuh bebas. Sementara jawaban siswa yang lain, mampu menjawab dengan benar bahwa peserta yang membuka parasut terakhir (ketinggiannya lebih rendah dari peserta lain) mendarat lebih cepat. Akan tetapi, siswa tersebut belum mampu menerapkan konsep gerak jatuh bebasnya. Sampel jawaban siswa disajikan pada Gambar 11.

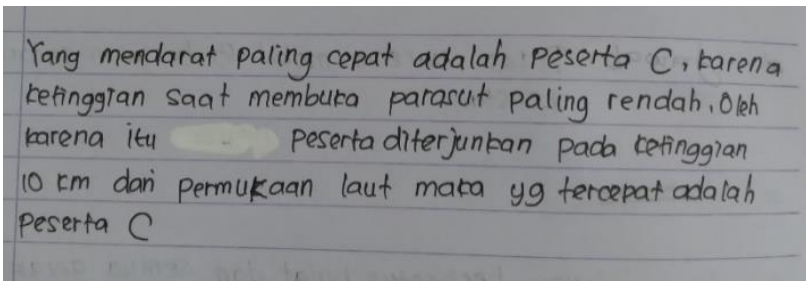

Gambar 11. Sampel Jawaban Siswa Nomor 6

Penjelasan yang lebih tepat adalah ketika peserta terjun tanpa parasut, maka ia akan mengalami gerak jatuh bebas. Pada saat itu, kecepatan peserta untuk jatuh sangat tinggi. Namun ketika parasut dibuka, akan ada hambatan udara yang mempengaruhi gerak jatuhnya sehingga kecepatan penerjun akan berkurang. Oleh sebab itu, yang paling cepat mendarat adalah yang paling terakhir membuka parasutnya.

Berdasarkan Tabel 2 dan analisis jawaban siswa, indikator kompetensi mengevaluasi dan mendesain penyelidikan ilmiah memiliki hasil yang lebih tinggi dari dua indikator lain. Hasil ini sejalan dengan penelitian (Alam et al., 2015). Sedangkan indikator yang memiliki ketercapaian "rendah" adalah indikator menjelaskan fenomena secara ilmiah serta menginterpretasi data dan bukti secara ilmiah. Rendahnya kemampuan literasi sains fisika pada domain menjelaskan fenomena secara ilmiah karena siswa juga belum mampu mengingat serta menerapkan pengetahuan ilmiah yang sesuai. Hasil ini sejalan dengan penelitian (Utama et al., 2019). Selain itu, menurut penelitian (Ning et al., 2020) sebagian siswa masih belum mampu memprediksi fenomena di sekitar secara ilmiah serta perubahan yang terjadi akibat fenomena tersebut. Hal ini didukung oleh analisis jawaban siswa pada soal nomor 4, siswa belum mampu menafsirkan fenomena dalam bentuk grafik. Indikator domain kompetensi yang paling rendah adalah menginterpretasi data dan bukti secara ilmiah. Hasil ini sejalan dengan penelitian (Merta et al., 2020). Rendahnya kemampuan literasi sains fisika pada domain menginterpretasi data dan bukti secara ilmiah, karena siswa kurang 
mampu menganalisis data untuk menarik kesimpulan yang tepat.

Penjelasan yang telah diuraikan memberikan informasi bahwa kemampuan literasi sains fisika dalam kategori rendah. Rendahnya kemampuan literasi sains fisika disebabkan karena peserta didik belum terbiasa menyelesaikan soal fisika yang berbasis literasi sains. Salah satu faktor yang memengaruhi kemampuan literasi sains siswa dilihat dari kemampuan mengerjakan soal-soal fisika adalah selama proses pembelajaran guru kurang memberikan layanan dan bimbingan kepada peserta didik dalam mengerjakan soal (Irwan, 2020).

Selain itu, proses pembelajaran sains masih bertumpu pada menghafal teori, hukum, dan konsep yang tujuan akhirnya adalah nilai (Arisman, 2015) dan siswa jarang melakukan kegiatan praktikum dan kurangnya pengetahuan siswa dalam ilmu pengetahuan dan teknologi (A Rusilowati et al., 2017) juga penyebab rendahnya kemampuan literasi sains siswa. Wawancara dengan guru fisika memberikan informasi bahwa proses pembelajaran daring belum melaksanakan kegiatan praktikum, khususnya di materi kinematika gerak lurus. Berdasarkan informasi tersebut, penyebab kemampuan literasi sains siswa rendah adalah merujuk kepada proses pembelajaran daring yang belum sesuai. Oleh sebab itu, upaya untuk meningkatkan kemampuan literasi sains fisika siswa sangat diperlukan dengan cara mendesain kembali proses pembelajaran.

Proses pembelajaran yang mampu mendorong semangat siswa untuk memecahkan masalah yang disajikan oleh guru, dan membangkitkan rasa ingin tahu mengenai topik pembelajaran, maka akan mampu membangun keterampilan proses sains yang merupakan bagian dari domain kompetensi literasi sains (Nurwulandari, 2018). Dalam rangka membangun dan mengembangkan literasi sains, guru dapat menerapkan pembelajaran yang berorientasi pada siswa aktif dalam memahami dan mengaplikasikan konsep yang telah dipelajari untuk menyelesaikan permasalahan yang dialami siswa pada kehidupan sehari-hari (Yuliati Y, 2017). Berdasarkan hasil penelitian $\mathrm{H}$ Sulsilah et al., (2019), peningkatan kemampuan literasi sains dapat dilakukan dengan menerapkan pendekatan saintifik dalam proses pembelajaran.

Peserta didik akan menikmati pengetahuan, menemukan keterkaitan, meningkatkan kemampuan kreatif dan tanggung jawab mereka dalam memecahkan masalah kehidupan seharihari melalui pembelajaran dengan pendekatan saintifik (Asyhari, 2015). Pada sintaks pendekatan saintifik, kegiatan eksplorasi dapat dilakukan dengan kegiatan praktikum. Kegiatan proses literasi sains berupa kegiatan praktikumpraktikum dapat menarik keingintahuan siswa serta memperkuat pemahaman siswa terhadap ilmu yang konkret melalui percobaan-percobaan (Rahayuningtyas et al., 2019).

Rendahnya kemampuan literasi sains fisika siswa di masa pandemi Covid-19 memberikan informasi bahwa proses pembelajaran daring hendaknya juga memperhatikan pengembangan kemampuan literasi sains fisika siswa. Oleh karena itu, perlu adanya kegiatan praktikum berbasis literasi sains untuk meningkatkan kemampuan literasi sains siswa walaupun dilaksanakan secara daring.

\section{KESIMPULAN}

Hasil analisis data dan pembahasan menunjukkan bahwa di masa pandemi Covid-19, kemampuan literasi sains fisika siswa SMA pada materi kinematika gerak lurus pada domain kompetensi masih dalam kategori pencapaian "rendah". Oleh sebab itu, kemampuan literasi sains fisika perlu ditingkatkan. Salah satu faktor rendahnya kemampuan literasi sains fisika ini adalah proses pembelajaran daring yang belum menerapkan kegiatan praktikum. Maka dari itu, upaya untuk meningkatkan kemampuan literasi sains fisika tersebut dapat dilakukan dengan cara melakukan 
kegiatan praktikum berbasis literasi sains secara daring.

\section{UCAPAN TERIMA KASIH}

Penulis mengucapkan terima kasih kepada Ibu Farida Fatkhiyati, S.Pd sebagai guru fisika di SMA Negeri 1 Jepara yang telah berkenan membantu dalam proses penelitian.

\section{DAFTAR PUSTAKA}

AAAS. (1990). Science for all Americans. American: University Press.

Adani, D. A. L., Astutik, S., \& Lesmono, A. D. (2018). Identifikasi kemampuan litersi sains pada materi gerak lurus kelas X MIPA SMA di SMAN Rambipuji. Prosiding Seminar Nasional Pendidikan Fisika 2018, 3(2), 184189.

Alam, D. P., Utari, S., \& Karim, S. (2015). Rekonstruksi Rancangan Rencana Pelaksanaan Pembelajaran Sains Melalui Analisis Kesulitan Literasi Sains Siswa SMP Kelas VII pada Topik Gerak Lurus. Prosiding Simposium Nasional Dan Pembelajaran Sains 2015 (SNIPS 2015), 317-320.

Andini, F., Jufri, A. W., \& Mahrus, M. (2020). Profil Literasi Sains Siswa SMP Di Kota Gerung Pada Tema Pencemaran Lingkungan. Jurnal Pijar Mipa, 15(4), 339-345

Arisman, A. (2015). Penerapan pembelajaran kooperatif tipe stad dengan metode praktikum dalam pembelajaran ipa terpadu untuk meningkatkan literasi sains siswa. Prosiding Seminar Nasional Fisika (EJournal) SNF2015 IV, 89-92.

Asyhari, A. (2015). Profil Peningkatan Kemampuan Literasi Sains Siswa Melalui Pembelajaran Saintifik. Jurnal Ilmiah Pendidikan Fisika Al-Biruni, 4(2), 179. https://doi.org/10.24042/jpifalbiruni.v4i2. 91

Firdaus, T., Erwin, E., \& Rosmiati, R. (2019). Learning media free fall motion to reduce misconceptions and improve students' understanding of the concept. Journal of
Physics: Conference Series (Vol. 1157, No. 3, p. 032072). http://doi.org/ 10.1088/17426596/1157/3/032072

Indrawati, M. D. (2018). Pengembangan Instrumen Penilaian Literasi Sains Fisika Peserta Didik Pada Bahasan Gelombang Bunyi Di Sma Negeri 1 Gedangan Sidoarjo. Jurnal Inovasi Pendidikan Fisika (JIPF), 07(1), $14-20$.

Irwan, A. P. (2020). Analisis Kemampuan Literasi Sains Pesrta Didik Ditinjau Dari Kemampuan Menyelesaikan Soal Fisika Di Sman 2 Bulukumba. Jurnal Sains Dan Pendidikan Fisika, 15(3), 17-24. https://doi.org/10.35580/jspf.v15i3.13494

Merta, I. W., Artayasa, I. P., Kusmiyati, K., Lestari, N., \& Setiadi, D. (2020). Profil Literasi Sains dan Model Pembelajaran dapat Meningkatkan Kemampuan Literasi Sains. Jurnal Pijar Mipa, 15(3), 223. https://doi.org/10.29303/jpm.v15i3.1889

Mijaya, N. P. A. P., Sudiatmika, A. A. I. A. R., \& Selamet, K. (2019). Profil Literasi Sains Siswa Smp Melalui Model Pembelajaran Levels of Inquiry. Jurnal Pendidikan Dan Pembelajaran Sains Indonesia (JPPSI), 2(2), 161.

https://doi.org/10.23887/jppsi.v2i2.19385

Naila, I., \& Khasna, F. T. (2021). Pengaruh pembelajaran daring terhadap kemampuan literasi sains calon guru sekolah dasar: sebuah studi pendahuluan. Jurnal Review Pendidikan Dasar: Jurnal Kajian Pendidikan dan Hasil Penelitian, 7(1), 42-47. http://dx.doi.org/10.26740/jrpd.v7n1.p4247

Ning, D. R., Roshayanti, F., \& Siswanto, J. (2020). Profil Literasi Sains Dan Berfikir Kreatif Siswa Smp Negeri 11 Pekalongan. Jurnal Edukasi Matematika dan Sains, 8(2), 150. https://doi.org/10.25273/jems.v8i2.6905

Nofiana, M. (2017). Profil Kemampuan Literasi Sains Siswa SMP di Kota Purwokerto Ditinjau dari Aspek Konten, Proses, dan Konteks Sains. JSSH Uurnal Sains Sosial Dan Humaniora), 1(2), 77. https://doi.org/10.30595/jssh.v1i2.1682 
Nurwulandari, N. N. (2018). N Pembelajaran Fisika Berbasis Literasi Sains terhadap Penguasaan Konsep Mahasiswa pada Pokok Bahasan Energi. Jurnal Pendidikan: Riset Dan Konseptual, 2(2), 205. https://doi.org/10.28926/riset_konseptual. v2i2.51

OECD. (2015a). PISA 2015 Framework. Oecd, March 2015, 52. https://doi.org/10.1177/00221465124690 14

OECD. (2015b). PISA Result in Focus.

OECD. (2018). Programme for International Student Assessment (PISA) Result from PISA 2018. Programme for International Student Assessment (PISA) Result from PISA 2018, 110. http://www.oecd.org/pisa/ Data

Pertiwi, U. D., Atanti, R. D., \& Ismawati, R. (2018). Pentingnya Literasi Sains Pada Pembelajaran Ipa Smp Abad 21. Indonesian Journal of Natural Science Education (IJNSE), 1(1), 24-29. https://doi.org/10.31002/nse.v1i1.173

Purwanto, N. (2013). Pengajaran, Prinsip-Prinsip dan Teknik Evaluasi. PT Remaja Rosdakarya.

Rahayuningtyas, W. A., Resmiyati, D., \& Purworejo, U. M. (2019). Pembelajaran ipa berbasis literasi sains dengan metode praktikum. Seminar Nasional Pendidikan Dasar. 75-86.

Rusilowati, A., Astuti, B., \& Rahman, N. A. (2019). How to improve student's scientific literacy. Journal of Physics: Conference Series, vol $1170 \quad$ No. 11 p. 012028. https://doi.org/10.1088/17426596/1170/1/012028

Rusilowati, A, Linuwih, S., \& Nugroho, S. A. (2017). The profile of science literacy attitudes of junior high school students in Purbalingga. Proceeding of ICMSE vol 4 No 1 pp. 183-189

Rusilowati, Ani, Kurniawati, L., Nugroho, S. E., \& Widiyatmoko, A. (2016). Developing an instrument of scientific literacy asessment on the cycle theme. International Journal of Environmental and Science Education, 11(12), 5718-5727.

Sukmadinata. (2012). Metode Penelitian
Pendidikan. Bandung: PT. Remaja Rosdakarya.

Sulsilah, H., Utari, S., \& Saepuzaman, D. (2019). The application of scientific approach to improve scientific literacy on domain competency at secondary school on dynamic electricity topic. Journal of Physics: Conference Series, Vol. 1157, No. 3, p. 032056. https://doi.org/10.1088/17426596/1157/3/032056

Turiman, P., Omar, J., Daud, A. M., \& Osman, K. (2012). Fostering the 21st Century Skills through Scientific Literacy and Science Process Skills. Procedia - Social and Behavioral Sciences, 59, 110-116. https://doi.org/10.1016/j.sbspro.2012.09.2 53

Utama, M. N., Ramadhani, R., Rohmani, S. N., \& Prayitno, B. A. (2019). Profil Keterampilan Literasi Sains Siswa Di Salah Satu Sekolah Menengah Atas ( Sma ) Negeri Di Surakarta Students ' Science Literacy Skill Profile in One of State High Schools in Surakarta. Didaktika Biologi: Jurnal Penelitian Pendidikan Biologi 3 (2), 57-67.

WEFUSA. (2015). Unlocking the potential of the smart grid. AIP Conference Proceedings, 1702. https://doi.org/10.1063/1.4938795

Yulianti, S. (2020). Hubungan antara kemampuan literasi saintifik dan keterampilan berpikir tingkat tinggi siswa pada materi kinematika gerak lurus. UIN Syarif Hidayatullah Jakarta. 